\title{
Mini-Tn7 transposons for site-specific tagging of bacteria with fluorescent proteins
}

\author{
Lambertsen, L.; Sternberg, Claus; Molin, Søren
}

Published in:

Environmental Microbiology

Link to article, DOI:

10.1111/j.1462-2920.2004.00605.x

Publication date:

2004

Document Version

Peer reviewed version

Link back to DTU Orbit

Citation (APA):

Lambertsen, L., Sternberg, C., \& Molin, S. (2004). Mini-Tn7 transposons for site-specific tagging of bacteria with fluorescent proteins. Environmental Microbiology, 6, 726-732. https://doi.org/10.1111/j.1462-2920.2004.00605.x

\section{General rights}

Copyright and moral rights for the publications made accessible in the public portal are retained by the authors and/or other copyright owners and it is a condition of accessing publications that users recognise and abide by the legal requirements associated with these rights.

- Users may download and print one copy of any publication from the public portal for the purpose of private study or research.

- You may not further distribute the material or use it for any profit-making activity or commercial gain

- You may freely distribute the URL identifying the publication in the public portal

If you believe that this document breaches copyright please contact us providing details, and we will remove access to the work immediately and investigate your claim. 


\section{The Tn7 transposon}

The Tn 7 transposon was originally discovered by Barth et al., (1976) on the plasmid $\mathrm{R} 483$ (IncI $\alpha$ ) as an element carrying the resistance genes trimethoprim $\left(\mathrm{Tm}^{\mathrm{R}}\right)$ and streptomycin/ spectinomycin $\left(\mathrm{Sm}^{\mathrm{R}} / \mathrm{Sp}^{\mathrm{R}}\right)$, which could be transposed to other replicons (note; in some earlier papers the $\mathrm{Tn} 7$ transposon is named $\mathrm{TnC}$ ).

The $\mathrm{Tn} 7$ transposon is $14 \mathrm{~kb}$. It contains five genes (Fig. 1), involved in the transposition process, and two resistance genes as described above. These genes are flanked by the ends of the transposon, named the left (Tn7L) and the right (Tn7R) end (Barth et al., 1976; Lichtenstein and Brenner, 1982; Rogers et al., 1986). Note; in the literature the names of the ends have not been used consistently. In the following the names used for the ends are as indicated in Fig. 1.

The Tn 7 transposition process has been studied intensively in Escherichia coli in which Tn7 inserts with high efficiency and unique orientation into one specific location named the att $\operatorname{Tn} 7$ site (Lichtenstein and Brenner, 1981; McKnown et al., 1988). This site of insertion is located just downstream of the coding region, in the transcriptional terminator, of the $g \operatorname{lm} S$ gene (Gringauz, et al., 1988). The transposon genes required for specific insertion into the att $\operatorname{Tn} 7$ site, are $\operatorname{tns} A B C D$, and they function in trans. Thus, sequences located in the 3 'end of the coding region of $g \operatorname{lm} S$ are recognised by transposase proteins and directing the actual insertion into the att $\operatorname{Tn} 7$ site, down-stream of the $\operatorname{glm} S$ gene (McKnown et al., 1988; Baiton et al., 1993). However, if this site is unavailable the transposon can insert into other sites with low frequency (Rogers et al., 1986; Kubo and Craig, 1990).

The $\mathrm{Tn} 7$ transposon recognises a sequence located in the terminal part of the $g \operatorname{lm} S$ gene, but it inserts just downstream of this and thereby it does not disrupt the gene (Gringauz, et al., 1988). The glmS gene encodes a glucosamine synthetase, which is required for cell wall synthesis (Volger et al., 1989). It is conserved among many bacteria and therefore $\mathrm{Tn} 7$ is likely to have the same specific insertion site in many different bacteria, some have already been tested (Table 1). Detailed information about the $\mathrm{Tn} 7$ transposon mechanisms can be found in the literature, two recommendable reviews are Craig (1989) and Peters and Craig, (2001).

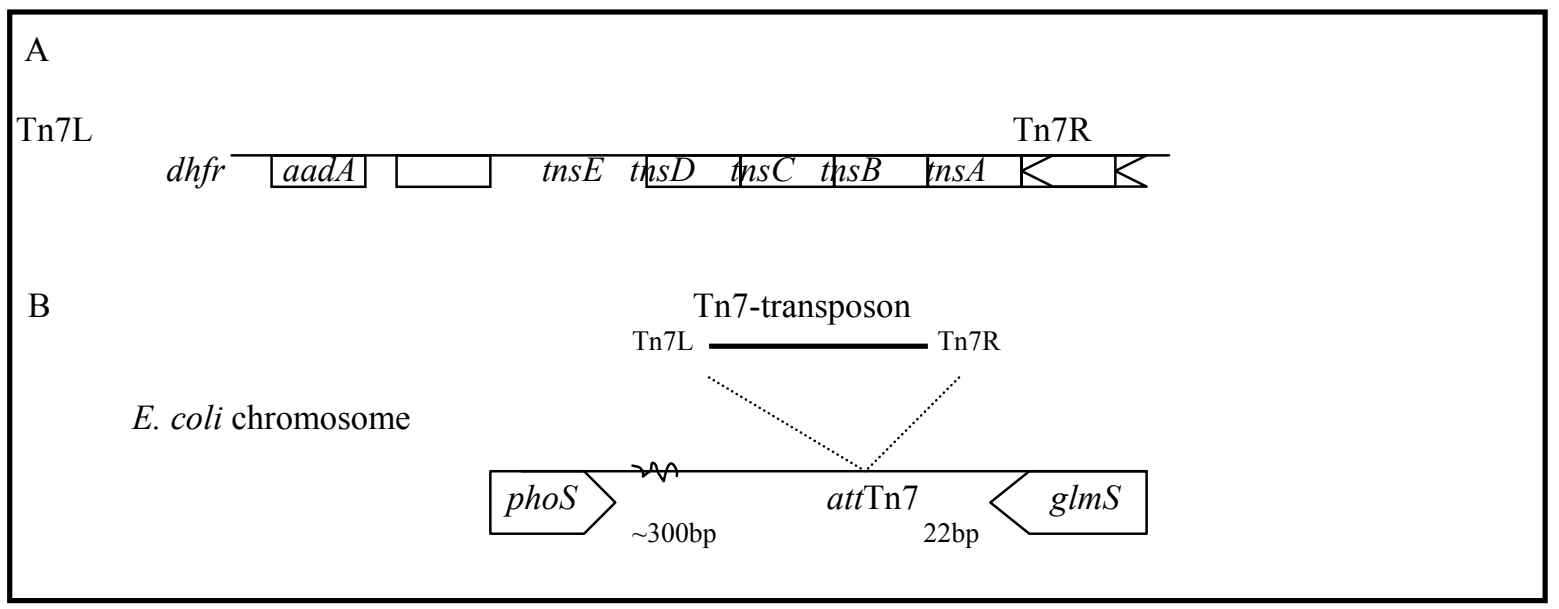

Fig. 1. Map of transposon $\operatorname{Tn} 7$ (A) and its insertion site att $\operatorname{Tn} 7$ in Escherichia coli (B). The gene $d h f r$ encodes dihydrofolate reductase providing trimethoprim resistance and aadA encodes adenylyltransferase, which provides resistance to streptomycin and spectinomycin (the figures are redrawn from Craig et al., 1989). 
Table 1. Literature overview of bacteria tested for insertion of $\operatorname{Tn} 7$

\begin{tabular}{|c|c|c|c|c|c|c|c|}
\hline Bacterium & \begin{tabular}{|l}
$\begin{array}{l}\text { Specific } \\
\text { insertion }\end{array}$ \\
\end{tabular} & Test & $\begin{array}{l}\begin{array}{l}\text { Sequence of } \\
\text { insertion site }\end{array} \\
\end{array}$ & $\begin{array}{l}\text { Numbers of } \\
\text { base pairs } \\
\text { downstream } \\
\text { of } g \operatorname{lm} S^{1}\end{array}$ & System tested $^{2}$ & Comments & References \\
\hline Caulobacter crescentus & Yes & Southern & - & - & RP4::Tn7 $7^{3}$ & 9 isolates tested & Ely et al., 1982 \\
\hline Desulfovibrio desulfuricans G20 & Yes & Southern & U46080 & 28 & RK2073::Tn7 $7^{3}$ & $\begin{array}{l}15 \text { out of } 16 \mathrm{~b} \text { had specific } \\
\text { insertion }\end{array}$ & Wallet al., 1996 \\
\hline Escherichia coli & Yes & Southern & AE000450 & 22 & ColE1::Tn7 $7^{3}$ & $\begin{array}{l}\text { Tested many times by different } \\
\text { scientists }\end{array}$ & $\begin{array}{l}\text { Lichtenstein and Brenner, } \\
1981 ; 1982\end{array}$ \\
\hline Escherichia coli BE6 & - & - & - & - & Grinter's system & Stable insertion & Grinter, 1983 \\
\hline Erwinia chrysanthemi $\mathrm{EC} 16$ & Yes & Southern & & & $\begin{array}{l}\text { Monsanto's } \\
\text { system }\end{array}$ & lux-based reporter system & Shen et al., 1992 \\
\hline Klebsiella pneumonia & - & - & - & - & I- & - & $\begin{array}{l}\text { In Caig 1989: Qadri et al } \\
\text { personal communication }\end{array}$ \\
\hline Methylophilus methylotrophus & - & - & - & - & Grinter's system & Stable insertion & Grinter, 1983 \\
\hline P. fluorescens CHA0 & Yes & Southern & - & - & Bao's system & $\begin{array}{l}\text { Specific insertion, no effect on } \\
\text { growth rate was observed }\end{array}$ & $\begin{array}{l}\text { Højberg et al., 1999; Zuber } \\
\text { et al., } 2003\end{array}$ \\
\hline Pseudomonas DS-S73 & Yes & - & - & - & Bao's system & Specific insertion & Koch et al., 2002 \\
\hline Pseudomonas S108 & Yes & - & - & - & Bao's system & Specific insertion & Koch et al., 2002 \\
\hline $\begin{array}{l}\text { Pseudomonas aeruginosa } \mathrm{PAC} \text { and } \\
\text { PAO1161 }\end{array}$ & Yes & Southern & - & F & $\begin{array}{l}\text { CAM- } \\
\text { OCT::Tn7 } 7^{3}\end{array}$ & 17 of 18 tested were similar & Caruso and Shapiro, 1982 \\
\hline
\end{tabular}

- not tested or described in the article.

${ }^{1}$ Number of base pairs were calculated from the stop codon to the middle base of the five base pairs that are duplicated upon insertion.

${ }^{2}$ Named according to the name of the original tagging system on which the used helper plasmid and delivery plasmids are based.

${ }^{3}$ Wild type $\mathrm{Tn} 7$ transposon located at the plasmid. 


\begin{tabular}{|c|c|c|c|c|c|c|c|}
\hline Bacterium & $\begin{array}{l}\text { Specific } \\
\text { insertion }\end{array}$ & Test & $\begin{array}{l}\text { Sequence of } \\
\text { insertion site }\end{array}$ & \begin{tabular}{|l} 
Numbers of \\
base pairs \\
downstream \\
of $g \operatorname{lm} S^{1}$
\end{tabular} & System tested $^{2}$ & Comments & References \\
\hline Pseudomonas aeruginosa $\mathrm{PAO} 1$ & Yes & Southern & - & - & Bao's system & - & Klausen et al., 2003 \\
\hline Pseudomonas aeruginosa $\mathrm{PAOE} 1 \mathrm{~A}$ & - & - & - & - & Grinter's system & Stable insertion & Grinter, 1983 \\
\hline Pseudomonas corrugate strain 2140 & - & Southern & - & - & Barry's system & $\begin{array}{l}\text { Strains was not changed after } 4 \\
\text { years in soil }\end{array}$ & Choi et al., 2003 \\
\hline Pseudomonas fluorescens 701E1 & Yes & Southern & - & - & $\begin{array}{l}\text { Monsanto’s } \\
\text { system }\end{array}$ & $\begin{array}{l}\text { Four isolates tested. Growth not } \\
\text { affected, stability tested }\end{array}$ & Barry, 1986 \\
\hline Pseudomonas fluorescens DR54 & Yes & PCR & AJ276127 & 29 & Bao's system & & Koch et al., 2001 \\
\hline Pseudomonas putida KT2440 & Yes & $\begin{array}{l}\text { PCR, } \\
\text { Southern }\end{array}$ & 4 & 25 & Bao's system & $\begin{array}{l}\text { Growth not affected, many } \\
\text { isolates tested, stable and } \\
\text { specific insertion }\end{array}$ & Lambertsen et al., 2003 \\
\hline Pseudomonas putida GR12-2 & Yes & Southern & & & $\begin{array}{l}\text { Monsanto's } \\
\text { system }\end{array}$ & & Staley et al., 1997 \\
\hline Pseudomonas putida $\mathrm{R} 20$ & No & Southern & & & $\begin{array}{l}\text { Monsanto's } \\
\text { system }\end{array}$ & & Staley et al., 1997 \\
\hline Pseudomonas putida $\mathrm{PH} 6$ & No & Southern & & & $\begin{array}{l}\text { Monsanto's } \\
\text { system }\end{array}$ & & Staley et al., 1997 \\
\hline Pseudomonas solanacearum & Yes & Southern & - & - & $\begin{array}{l}\text { pAS8Rep- } \\
1:: \operatorname{Tn} 7^{3}\end{array}$ & $\begin{array}{l}16 \text { isolates tested, suicide } \\
\text { system used }\end{array}$ & Boucher et al., 1985 \\
\hline $\begin{array}{l}\text { Pseudomonas syringae pv. glycinea } \\
\text { PsgR4 }\end{array}$ & Yes & Southern & & & $\begin{array}{l}\text { Monsanto's } \\
\text { system }\end{array}$ & lux-based reporter system & Shen et al., 1992 \\
\hline Rhodospirillum rubum & - & Southern & - & - & Bao's system & $\begin{array}{l}\text { Stable, stability tested for } 50 \\
\text { generations }\end{array}$ & Bao, 1991 \\
\hline
\end{tabular}

${ }^{4}$ Sequenced PCR product of the region between Tn7R and glms: CAGTTGATCAACACCTGACTACCCG 


\begin{tabular}{|l|l|l|l|l|l|l|l|}
\hline Bacterium & $\begin{array}{l}\text { Specific } \\
\text { insertion }\end{array}$ & Test & $\begin{array}{l}\text { Sequence of } \\
\text { insertion site }\end{array}$ & $\begin{array}{l}\text { Numbers of } \\
\text { base pairs } \\
\text { downstream } \\
\text { of } \boldsymbol{g l m} \mathbf{S}^{\mathbf{1}}\end{array}$ & System tested & Comments & References \\
\hline Salmonella thyphimurium & - & - & - & - & - & - & $\begin{array}{l}\text { In Caig 1989: Mak and } \\
\text { Craig, unpub observation }\end{array}$ \\
\hline Serratia marcescens & - & - & - & - & - & - & $\begin{array}{l}\text { In Caig 1989: Qadri } \text { et al., } \\
\text { personal communication }\end{array}$ \\
\hline Sphingomonas yanoikuyae B1 & Yes & Southern & U37523 & 93 & RKTV14::Tn7 & - & Wang and Lau, 1996 \\
\hline $\begin{array}{l}\text { Xanthomonas campestris pv. } \\
\text { campestris NC PPB 1145 }\end{array}$ & Yes & Southern & - & - & pRK2013:: Tn7 & 10 tested & Turner et al, 1984 \\
\hline
\end{tabular}




\section{References}

Bainton, R. J., K. M. Kubo, J.-N. Feng, and N. L. Craig (1993). Tn7 transposition: Target DNA recognition is mediated by multiple Tn7-encoded proteins in a purified in vitro system. Cell 72: 931-943.

Bao, Y., D. P. Lies, H. FU, and G. P. Roberts (1991). An improved Tn7-based system for the single-copy insertion of cloned genes into chromosomes of Gram-negative bacteria. Gene 109: $167-168$.

Barry, G. F. (1986). Permanent insertion of foreign genes into the chromosome of soil bacteria. Bio/Technology 4: 446-449.

Barth, P. T., N. Datta, R. W. Hedges, and N. J. Grinter (1976). Transposition of a deoxyribonucleíc acid sequence encoding trimethoprim and streptomycin resistances from R483 to other replicons. J. Bacteriol. 125: 800-810.

Boucher, C. A., P. A. Barberis, A. Ph. Trigalet, and D. A. Demery. (1985). Transposon mutagenesis of Pseudomonas solanacearum: Isolation of Tn5-induced avirulent mutants . J. Gen. Microbiol. 131: 2449-2457.

Caruso, M. and J. A. Shapiro (1982). Interactions of Tn7 and temperate phage F116L of Pseudomonas aeruginosa. Mol. Gen. Genet. 188: 292-298.

Choi, H. Y., M. H. Ryder, M. R. Gillings, H. W. Stokes, K. M. Ophel-Keller and D. A. Veal. (2003). Survival of a lacZY-marked strain of Pseudomonas currugata following a field release. FEMS Microbiology Ecology 43, 367-374.

Craig, N. L. (1989). Chapter 7, Transposon Tn7, p. 211-225. In D. E. Berg and M. M. Howe (eds.), Mobile DNA. American Society for Microbiology, Washington,DC.

Ely, B. (1982). Transposition of $\operatorname{Tn} 7$ occurs at a single site on the Caulobacter crescentus chromosome. J. Bacteriol. 151: 1056-1058.

Gringauz, E., K. A. Orle, C. S. Waddell, and N. L. Craig (1988). Recognition of Escherichia coli att $\operatorname{Tn} 7$ by transposon Tn7: Lack of specific sequence requirements at the point of $\operatorname{Tn} 7$ insertion. J. Bacteriol. 170: 2832-2840.

Grinter, N. J. (1983). A broad-host-range cloning vector transposable to various replicons. Gene 21: 133-143.

Højberg, O., U. Schnider, H. V. Winteler, J. Sørensen, and D. Haas (1999). Oxygen-sensing reporter strain of Pseudomonas fluorescens for monitoring the distribution of low-oxygen habitats in soil. Appl. Environ. Microbiol. 65: 4085-4093.

Klausen, M., Heydorn, A., Ragas, P., Lambertsen, L., Aaes-Jørgensen, A., Molin, S. and Tolker-Nielsen, T. (2003). Biofilm formation by Pseudomonas aeruginosa wild type, flagella and type IV pili mutants. Molecular Microbiology 48, 1511-1524. 
Koch, B., L. E. Jensen, and O. Nybroe (2001). A panel of Tn7-based vectors for insertion of the $g f p$ marker gene or for delivery of cloned DNA into Gram-negative bacteria at a neutral chromosomal site. J. Microbiol. Meth. 45: 187-195.

Lambertsen, L. M., Sternberg, C. and S. Molin (2004). Mini-Tn7 transposons for sitespecific tagging of bacteria with fluorescent proteins. Environ. Microbiol. In press.

Lichtenstein, C. and S. Brenner (1981). Site-specific properties of Tn7 transposition into the E. coli chromosome. Mol. Gen. Genet. 183 : 380-387.

Lichtenstein, C. and S. Brenner (1982). Unique insertion site of Tn7 in the E.coli chromosome. Nature 297: 601-603.

McKown, R. L., K. A. Orle, T. Chen, and N. L. Craig (1988). Sequence requirements of Escherichia coli att Tn7, a specific site of transposon Tn7 insertion. J. Bacteriol. 170: 352358.

Peters, J. and N. L. Craig (2001). TN7: Smarter than we thought. Nature Reviews Molecular Cell Biology 2, $806-814$.

Rogers, M., N. Ekaterinaki, E. Nimmo, and D. Sherratt (1986). Analysis of Tn7 transposition. Mol. Gen. Genet. 205: 550-556.

Shen, H., S. E. Gold, S. J. Tamaki, N. T. Keen (1992). Construction of a Tn7-lux system for gene expression studies on Gram-negative bacteria. Gene 122, 27 -

Staley, T. E., E. G. Lawrence, D. J. Drahos (1997). Variable specificity of Tn7::lacZY insertion into the chromosome of root-colonizing Pseudomonas putida strains. Mol. Ecol. 6, 85-87.

Turner, P., C. Barber, and M. Daniels (1984). Behaviour of the transposons Tn5 and Tn7 in Xanthomonas campestris pv. campestris. Mol. Gen. Genet. 195: 101-107.

Vogler, A. P, S. Trentmann, J. W. Lengeler (1989). Alternative route for biosynthesis of amino sugars in Escherichia coli K-12 mutants by means of a catabolic isomerase. $\mathrm{J}$.

Bacteriol. 171: 6586-6592.

Waddell, C. S. and N. L. Craig (1989). Tn7 transposition: Recognition of the att $\operatorname{Tn} 7$ target sequence. Proc. Natl. Acad. Sci. U. S. A. 86: 3958-3962.

Wall, J. D., T. Murnan, J. Argyle, R. S. English, and B. J. RappGiles (1996). Transposon mutagenesis in Desulfovibrio desulfuricans: Development of a random mutagenesis tool from Tn7. Appl. Environ. Microbiol. 62: 3762-3767.

Wang, Y. and P. C. K. Lau (1996). Sequence and expression of an isocitrate dehydrogenaseencoding gene from a polycyclic aromatic hydrocarbon oxidizer, Sphingomonas yanoikuyae B1. Gene, 168: 15-21. 
Zuber, S., F. Carruthers, C. Keel, A. Mattart, C. Blumer, G. Pessi, C. Gigot-Bonnefoy, U. Schnider-Keel, S. Heeb, C.. Reimmann and D. Haas (2003). GagS sensor domains pertinent to the regulation of exoproduct formation and to the biocontrol potential of Pseudomonas fluorescens CHA0. Mol. Plant-Microbe Interact. 16, 634-644. 